\title{
Lewis and Schlick
}

Verificationism between Pragmatism and Logical Empiricism

\section{Massimo Ferrari}

\section{(2) OpenEdition \\ 1 Journals}

Electronic version

URL: http://journals.openedition.org/ejpap/1516

DOI: $10.4000 /$ ejpap. 1516

ISSN: 2036-4091

Publisher

Associazione Pragma

\section{Electronic reference}

Massimo Ferrari, «Lewis and Schlick », European Journal of Pragmatism and American Philosophy

[Online], XI-1 | 2019, Online since 19 July 2019, connection on 21 July 2019. URL : http://

journals.openedition.org/ejpap/1516 ; DOI : 10.4000/ejpap.1516

This text was automatically generated on 21 July 2019.

\section{(c) $(1)$}

Author retains copyright and grants the European Journal of Pragmatism and American Philosophy right of first publication with the work simultaneously licensed under a Creative Commons Attribution-

NonCommercial-NoDerivatives 4.0 International License. 


\title{
Lewis and Schlick
}

\author{
Verificationism between Pragmatism and Logical Empiricism
}

\author{
Massimo Ferrari
}

\section{Lewis's Pragmatic A Priori}

1 In 1937 Otto Neurath claimed that in a country like the United States, "in which Peirce, James, Dewey and others have created a general atmosphere that is empiricist in many respects," the philosophical insights of the Vienna Circle and related groups were friendly and welcome. "The very fertile American manner of thinking," Neurath added, "successfully combines with the European in this field, and important results may probably be expected from such cooperation" (Neurath 1983: 190). Some years before, Charles Morris had stressed, for his part, that Pragmatism and Logical Empiricism "are essentially complementary" so that "much is to be expected from a conscious crossfertilization of the two tendencies" (Morris 1937: 23). According to Morris, a new scientific empiricism was in the making, thanks to a kind of pre-established harmony between the Vienna Circle and American pragmatism. Thus, both Neurath and Morris were in perfect agreement with a view of the relationship between Pragmatism and Logical Empiricism that would have until recent time been recognized as the official history of a successful "cross-fertilization." New scholarship, however, has shown that, at least for two main reasons, the story is more complicated than is usually assumed. On the one hand, before the emigration of the Vienna Circle from Europe to the United States during the 1930s, Logical Empiricism and Pragmatism inaugurated a very fruitful collaboration, and increased significant affinities (Ferrari 2017). On the other hand, today it is no longer admissible to contend that a supposed "dogmatic" Logical Empiricism "was driven by a much more liberal Pragmatism to a liberal turn," profiting thereby - as Neurath suggested - from the "very fertile" American way of thinking (see LimbeckLilienau 2012: 108).

2 In order to shed new light on this very intricate network of conceptual and historical relations, attempting a closer examination of the case study "Lewis and Schlick" seems to be of some interest. To be sure, the general historical and biographical context of this 
fascinating history (though to be told in detail elsewhere) had been originated by the relationship between Schlick and the Anglo-Saxon milieu since the end of the 1920s. Schlick's stay as visiting professor at Stanford in 1929 and at Berkley in 1931/32, his participation in the Seventh International Congress of Philosophy in Oxford in 1930, and finally the lectures on Form and Content he delivered in London in 1932 testify to "a bilateral (and intercontinental) exchange of ideas" between the Vienna Circle and the philosophical communities both in Great Britain and the United States (Stadler 2003: 167; Stadler 2007: 582). Schlick was not the only one to give impulse to the international dialogue within the scientific philosophy of that time, but he also played a very important role, not least due to the publication of several articles in English in the last years of his life. $^{1}$

In 1929, the same year as Schlick's stay at Stanford, Lewis's philosophical masterpiece Mind and World Order saw the light. This profound, but hitherto over-neglected book was the result of a research program devoted to a pragmatic theory of A priori. Lewis had sketched the main lines of this original theory in 1923, when he overcame the first step of his philosophical career through the influential A Survey of Symbolic Logic, first published in 1918 and deeply inspired by his "friend and teacher" Josiah Royce (Lewis 1918: vi). The brief essay A Pragmatic Theory of the A Priori and the more detailed contribution of 1926 on The Pragmatic Element in Knowledge offer a clear account of Lewis's major philosophical project. More precisely, Lewis was engaged in framing a "conceptual pragmatism" which represents quite an original contribution to both alternative conceptions of A priori elaborated by Ernst Cassirer and Arthur Pap (Stump 2011; Stump 2015: 94-101; Stump 2017), and the debate about the "relativization of A priori" within the early Logical Empiricism (Mormann 2012: 113-4). Lewis's very idea of "pragmatic A Priori," as well as of "conceptual pragmatism," rests upon the articulation of a theory of knowledge in three elements (Calcaterra 2009). First, A priori are only the logic-mathematical concepts established by definition, without any reference to sense-qualities or things given in experience (Lewis 1970: 244). They are nonetheless "principles of procedure": namely, their principal function is a "pragmatic" one, as well as prior to the process of investigation (Lewis 1970: 232, 234). A priori signifies thus independent of experience, "but precisely," Lewis contended, "because it prescribes nothing to experience" (Lewis 1970: 231). Second, the given of experience is a totally independent element from thought, purely belonging to experience as such. The given is in no way affected by thought and in any case subsists in itself before perception or any form of relation to the mind (Lewis 1970: 248). Finally, the interpretation of experience rests upon the activity of mind and is more than experience itself, being that "truth," as Lewis maintained in genuine pragmatic spirit, "is made by mind" (Lewis 197: 240, 248-9). According to Lewis, however, the active interpretation provided by mind is not rooted in a fixed system of a priori categories as conceived by Kant (Lewis 1970: 241). This does not mean, though, that knowledge would be possible without "a network of categories and definitive concepts" exploring experience (Lewis 1970: 237). Pragmatism, in contrast, outlines a conception of mind that fully recognizes the priority of "the act of interpretation with its practical consequences" (Lewis 1970: 240). In a later essay of 1941, Lewis will state that the "emphasis upon relevance to some active intent" represents precisely the point of difference between Pragmatism and Logical Positivism. While the former is more or less interested in the sophisticated techniques of empirical testability (meaning here Rudolf Carnap), the latter omits "largely or wholly" the activity of human mind, and conceives of 
experience essentially in the sense of physicalism, namely too far from the language of everyday experience (Lewis 1970: 94, 103).

4 Accordingly, in his major work of 1929 Lewis endorsed a philosophical point of view rooted in the tradition of American pragmatism, and in particular Peirce's thought, though still largely dependent upon Kantian epistemology in a broad sense. According to Sandra B. Rosenthal, "the work is strongly and consciously Kantian in its focus on 'categories,' though as always with Lewis, the Kantian schematic undergoes a radical transformation" (Rosenthal 2007: 16). To be sure, this "transformation" represents the core of Lewis's philosophical enterprise and can be acknowledged as his most important contribution to contemporary philosophy. One can even remark that Lewis anticipated, to some extent, the later discussion on "conceptual schemes" that would, from the 1950 s on, animate analytical philosophy (Beck 1953/54; Beck 1968). Similarly, the forwardlooking critique of the "myth of the given," which would take a key role in philosophical agendas only after Wilfried Sellar's celebrated contribution of 1956, had already been developed by Lewis, albeit within his own peculiar perspective, in Mind and World Order. ${ }^{2}$ In Lewis's mind, at stake here is not the claim that the given can be altered or even ignored by our thinking, but that empirical data is always in need of interpretation by means of our thought (a typical Peircean point of view, as one can easily comprehend). ${ }^{3}$ Lewis unambiguously says: "We cannot describe any particular given as such because in describing it, in whatever fashion, we qualify it by bringing it under some categories or other, select from it, emphasize aspects of it, and relate it in particular and avoidable ways." (Lewis 1929: 52). The field of the given belongs therefore to a specific context. Knowledge means going beyond the given, but this is possible only by using conceptual schemes delimiting, in Kantian terms, the "possible experience," or, in a pragmatist sense, the workability of the schemes. The relationship between scheme and given makes it possible to determine what the given properly is. In other words, knowing an object implies the activity of mind and requires its "integration." As Lewis very clearly argues: "For the merely receptive and passive mind, there could be no objects and no world." (Lewis 1929: 137).

5 At the center of Lewis's conceptual Pragmatism lies therefore the very idea of philosophy as inquiry into the nature both of A priori and categories we use in framing our knowledge. And knowledge means for Lewis the equipment of all the concepts exhibiting the propriety of "common, shareable and expressible meaning" (Lewis 1929: 80). Mathematics offers, in this sense, the best illustration of a similar "body of truth which may rise [both] from pure concepts" and logical relations having no reference to sensequalities of any sort (Lewis 1970: 244). According to Lewis W. Beck, Lewis once affirmed he was a Kantian, but a Kantian - he paradoxically explained - "who disagrees with every sentence of the Critique of Pure Reason" (Beck 1968: 273). There is no doubt, however, that what is distinctive in Mind and World Order is exactly the rethinking of Kant's theory of A priori in a very unusual manner, though Lewis's greatest philosophical debt was indeed to Kant (Murphey 2006: 99).

6 To begin with, Lewis conceives the Kantian a priori in a pragmatic and not in a synthetic sense. More precisely, the very function of a priori consists of classifying and ordering the empirical material, although the crucial point is rather that for Lewis the authentic character of a priori resides in its analyticity: "The a priori is not a material truth, delimiting or delineating the content of experience as such, but is definitive or analytic in its nature." (Lewis 1929: 231). A priori is something valid or truth by definition, upon which the experience 
depends in so far as analytic rules or stipulations embrace the conditions enabling our relationship to experience. By recognizing the analytical A priori as fundamental in order to constitute experience, Lewis proposes a sort of challenge to traditional Kantianism, because analytical statements a priori become the condition of possibility of experience in general. Lewis seems to be in no doubt over what concerns this crucial aspect: "The naming, classifying, defining activity is at each step prior to the investigation. We cannot even interrogate experience without a network of categories and definitive concepts. Until our meanings are definite and our classifications are fixed, experience cannot conceivably determine anything." (Lewis 1929: 259). To be further stressed here is that Lewis refers to (intentional) "meanings" in the sense of "criteria of application" of verbal expressions, determining in advance the "testable and sense-recognizable characters" of field of application (Lewis 1946: 157). ${ }^{4}$

7 A second intervention on the Kantian A Priori in Lewis's conceptual Pragmatism, on the other hand, focuses on the treatment of the classical problem of categories. His main issue consists of recognizing the set of categories we employ in our knowing with a dynamic character, similarly to the analogue attempt developed by the Neo-Kantian Cassirer that Lewis once sympathetically quotes (Lewis 1929: 363*). According to Lewis's account, we are to work with a "list of categories" (as the young Peirce would have said), including, e.g., substance, accident, cause, effect, thing, content, event, propriety, law and so on. These relatively vague categories are, properly speaking, "guides to action" (Lewis 1929: 21), that is, instruments whose validity is testified through the practice both of knowledge and linguistic communication. Moreover, the very idea of a priori - which at first glance "smacks of magic and superstitious nonsense," as Lewis ironically remarks (Lewis 1929: 22) - can be considered as something prior to experience, precisely as a purpose is prior to the goal to be reached (Lewis 1929: 24). Hence, for Lewis, what is more important is that categories are necessary in order to enable experience - namely to make it possible - in a genuinely Kantian sense: "The world of experience is not given in experience: it is constructed by thought from the data of sense." (Lewis 1929: 29). And Lewis goes on: "The categories are ways of dealing with what is given to the mind, and if they had no practical consequences, the mind would never use them." (Lewis 1929: 31). "Practical consequences" also legitimate the validity of the categories; and in this sense the Kantian deduction of categories is still acceptable, or more precisely it is acceptable in the sense that both the practical use and success of conceptual frameworks determine the possibility of experience, without any postulation of unique "modes of intuition" or "fixed forms of thought" (Lewis 1929: 320). Nonetheless, to reject the "transcendental and miraculous status" of categories as eternal structures of human Reason does not imply, in Lewis's mind, eliminating their function as rules finding an exemplification in the "very wide range of heterogeneous sensory content" (Lewis 1929: 99-100). From this point of view, the pragmatist Lewis acknowledges his own indebtedness to the Kantian legacy; or one could affirm that "we must all be pragmatists in the end, not in the beginning" (Lewis 1929: 267).

\section{Schlick, Lewis and Verificationism}

8 Bearing this maxim in mind, in the early 1930s Lewis contacted Schlick and Carnap, making an effort in bridging the gap between Pragmatism and Logical Empiricism. The first important upshot of this intellectual exchange is mirrored in Lewis's article 
"Experience and Meaning" (published in 1933 in The Philosophical Review), where he brought to attention the danger of solipsism he saw in Schlick's and Carnap's criterion of verification through direct experience, dangerous because it is based on the subjective experience lived by the Ego. For Lewis, by contrast, cognition is guided by "an element of anticipation" foreshadowing the datum. Hence, verification indicates the potential for "being verifiable," a word connoting - like any word ending in "able" - possibility in general, and in particular the conditions under which the verification can be projected and obtained (for instance when we consider a sentence regarding the other side of the moon)..$^{5}$ In a nutshell, Lewis intended to rework the logical-positivistic conception of verification by pointing out that "to know (empirically) is to be able to anticipate correctly further possible experience" (Lewis 1970: 268).

Lewis also recasts the concept of experience in the sense of a kind of "activity," underlying thereby the main difference between Pragmatism and Logical Empiricism. "The pragmatic emphasis upon relevance to some active intent," Lewis holds, "is largely or wholly omitted in logical positivism" (Lewis 1970: 94). Note that by "logical positivism" Lewis here means exclusively Carnap, who had, in Lewis's eyes, excluded precisely what was supposed to be at the heart of a pragmatic conception of meaning. This is understood not only in the sense of what the logical positivists mean by "protocols" or "observation sentences" over and against what the pragmatists mean by the "content of experience," but also in the sense that Carnap's logical syntax overlooks the distinction between linguistic meaning and empirical meaning, "which concerns the relation of expressions to what may be given in experience" (Lewis 1970: 96-7). It is precisely at this point that Schlick enters the scene through an extensive answer to Lewis, which places great emphasis on the concept of verifiability. Before considering Schlick's position in detail, however, it is worth recalling that from the early days of his philosophical development he had manifested a sharp disagreement with the pragmatist conception of truth and, in particular, with James's own. In his dissertation on The Nature of Truth in Modern Logic, published in 1910, Schlick already deemed as false (or even "unscientific") the pragmatist theory of truth, because it confuses the essence of truth with both the criteria of its verification and its practical consequences (Schlick 1979, vol. I: 67). Schlick found James's account of truth unacceptable for two main reasons: on the one hand, because while all true judgments have to be verified, it does not follow, conversely, that all the judgments that are (or can be) verified are true; on the other hand, because James's definition attributes to truth in general "a property uncharacteristic of it in either everyday or scientific language, namely that of mutability" (Schlick 1979, vol. I: 64-5). Hence Schlick's claim that he differed "sharply from pragmatism" (Schlick 1979, vol. I: 88), maintaining by contrast that truth is the "one-to-one coordination" of judgments with some "statesof-affairs." This insight would be at the center of Schlick's main work too, i.e. the General Theory of Knowledge from 1918, where he emphasizes once again his disagreement with James's Pragmatism, suggesting rather - as he already did in 1910 - that "the great merit" of Pragmatism consists exactly of considering the "process of verification" as "the only way of recognizing the univocal nature, and thus the truth, of the judgment" (Schlick 1979, vol. I: 96; Schlick 1974: 165).

10 Twenty-five years after his youthful study on the concept of truth, Schlick would have the occasion to reconsider his previous view on the pragmatist procedure of verification. Needless to say, in the meantime the context had become quite different from at the time of Schlick's first writings. In the early 1930s Schlick was involved in the protocol sentence 
debate; he had become a long-time devoted admirer of Wittgenstein; and, last but not least, he had endorsed a new conception of philosophy as an activity of linguistic clarification. Nonetheless, a subtle link to Pragmatism seems to re-emerge in his very influential paper "Meaning and Verification," which appeared under the auspices of Lewis himself in the July 1936 issue of The Philosophical Review. Actually, Schlick's article required careful preparation and was published not long after his tragic death. It can also be considered as his philosophical testament, a kind of message in the bottle for further developments in Logical Empiricism and analytic philosophy (see Schlick 2008: 703-7).

Interestingly enough, in 1936 Schlick claimed that Lewis's remarks on verifiability seemed to be in "perfect agreement" with Viennese Empiricism (Schlick 2008: 716). As a convinced, enthusiastic follower of Wittgenstein's conception of meaning, Schlick maintained that the meaning of a proposition consists of "the method of its verification" (Schlick 2008: 712). The core argument here is that verification means, exactly as Lewis suggests, "possibility of verification," that is "verifiability," but not "verifiable here now" or "being verified now." In Schlick's own words: "Verifiability means possibility of verification." (Schlick 2008: 717-8, 720). Furthermore, it is quite crucial to bear in mind that for Schlick the possibility of verification always means the logical possibility. The empirical verification concerns the truth of a proposition, for instance its accordance with the laws of nature, or lack thereof. By contrast, the meaning of a proposition, i.e. the question about its sense, may be posed only in the framework of the logical possibility of verification. Note that precisely this point was at stake in the November 1934 discussion between Schlick and Carnap concerning the Lewis' essay, to which Carnap also aimed to respond. For Schlick it was implausible to assume, as Carnap did, that the logical possibility of verification could be in contrast with the laws of nature, because in that case dismissing a natural law would imply that natural laws can be meaningless (RC 029-28-08). Meaningless propositions, by contrast, are, in Schlick's opinion, the propositions that represent logical impossibilities (Schlick 2008: 723; see also Friedl 2013: 103-4). A further consequence is thus that verifiability as logical possibility represents the sufficient and necessary condition of meaning, showing at once that a meaningful problem can not be "insoluble in principle" (Schlick 2008: 726). And the very example Schlick brings to one's attention is again the question posed by Lewis about the other side of the moon (Schlick 2008: 728). Accordingly, Schlick underlines that "it will be easy to show that there is no serious divergence between the point of view of the pragmatist as Professor Lewis conceives it and that of the Viennese Empiricist" (Schlick 2008: 716).

In answering to Schlick's proposal to discuss "Experience and Meaning," Lewis remarked, in a letter dated December 14, 1934, that with regard to verification the point was perhaps not clear. Lewis's doubt was in particular about the solipsism vindicated by Carnap but, according to Lewis, also implicit in Schlick's own verificationism. Lewis wrote: "I have not intended to accuse the Vienna Circle of metaphysical solipsism; I have meant to indicate that, for you, the issue between metaphysical solipsism and any metaphysical alternative is meaningless; and I have meant to take exception to that conclusion." (Schlick Nachlaß, Inv. 107/Lewis - 1). Actually, Lewis was convinced that to ascribe to the act of knowing a solipsistic character was "no more strange or fantastic than Kant's transcendental unity of apperception" (Lewis 1970: 262). For his part, Schlick too was not satisfied with Carnap's "methodological solipsism" and in his response to Lewis he defined Carnap's terminological choice "unfortunate" (Schlick 2008: 735). Schlick stressed that, on a closer look, Carnap's formulation would reveal not a kind of 
solipsism, but rather "a method of building concepts" (Schlick 2008: 735). And this move provided Schlick with the opportunity of bringing up for discussion the mistake affecting any manner of considering the mind as something inside the body: the mistake, he explained, that characterizes "the idealistic fallacy which leads to solipsism," and whose danger Lewis had rightly denounced (Schlick 2008: 737). ${ }^{6}$

Schlick's late convergence with Lewis, along with his warm interest in Percy W. Bridgman's The Logic of Modern Physics (Schlick 2008: 187-91, 714), thus testifies to an increasing dialogue between Logical Empiricism and American Pragmatism, even before the dissolution of the European scientific community. They represent - as Alan W. Richardson has rightly underlined - "kindred rather than opposing projects" (Richardson 2003: 1). From a philosophical point of view, the question is whether a careful (re)examination of the Schlick and Lewis case can suggest a possible third way beyond the parting of the ways Schlick had initially seen at the time of the first reception of what he had called in 1910 "unscientific" Pragmatism in Germany. It seems plausible to suggest that Lewis's conceptual pragmatism and Schlick's late conception of meaning and verification found a significant convergence point in verificationism, although their respective origins remain doubtless very different and, to some extent, mutually extraneous. ${ }^{7}$ It is not by accident, we may add, that Lewis played a leading role in rediscovering in the 1930s the father of pragmatism, Charles Sanders Peirce, thereby posing the premises for further developments of the movement, as later exemplified, for instance, by Willard V. O. Quine. In 1981 Quine himself suggested that Peirce's famous pragmatic maxim could be considered as the first attempt to elaborate a verifiability theory of meaning similar to that shared by the Vienna Circle in its final period (Quine 1981: 30). Moreover, one can suggest that Peirce's late philosophy offered a sophisticated account of what verification means, inasmuch as Peirce never believed in the "myth" of definite testability of empirical sentences (Chauviré 2001). In this respect Peirce anticipated the "liberalization" of empiricism later pursued by Carnap, though his conception of experience was at any rate "much richer" - according to Hookway - than the Viennese verificationism was able to formulate (Hookway 2013: 33).

The later realignment of Pragmatism along Pierce's positions is of crucial importance to understand Lewis' own views regarding Logical Empiricism. In vindicating Peirce's selfidentification with a kind of metaphysics Lewis aimed to stress how metaphysical questions, that is more general questions not to be tested by empirical verification, can play a crucial role in orienting inescapable and more general discussions about both the nature of knowledge and science. As Lewis argued in 1941: "There are questions with respect to which some decision must be made in the interest of any theory of science or of knowledge in general, or of the character of experience in general, with respect to which any limited set of experiments or observations, such as those of the natural sciences, is either unnecessary or futile or both." (Lewis 1970: 106). The Logical Positivists, Lewis contended, have totally excluded a similar function of metaphysics conceived, we might say, as a kind of general framework within which it would be possible to treat philosophical questions as a class of statements that surely have meaning, but are not verifiable "under human conditions, and do not belong to the field of science" (Lewis 1970: 107). Was this insight compatible with Schlick's philosophical rejection of metaphysics and with the linguistic turn he had advocated since the early 1930s? This question leads to a third issue, unfortunately to date little considered by scholarship. 


\section{Verificationism and Ethical Values}

Following Lewis's own suggestions, a final point must thus be stressed. In his article on "Logical Positivism and Pragmatism" Lewis pointed out an aspect that very well summarizes what is at stake here. "It is with respect to problems of evaluation and of ethics," Lewis suggested, "that the contrast between logical positivism and pragmatism is strongest [...] For the pragmatist there can be no final division between 'normative' and 'descriptive'." (Lewis 1970: 106, 112). As Lewis had written to Schlick in 1934, "the line between the empirical and verifiable and the metaphysical and meaningless" seemed drawn "a little too sharply" when we consider "the objectivity of judgments of values." This is just the point we need to emphasize in order to properly account for the discussion between Schlick and Lewis about verificationism. According to the standard view of the Vienna Circle, moral judgments and ethical norms in general do not belong to the sphere of cognitive meanings, and consequently, unlike meaningful propositions, they are unconcerned with the value of truth or falsity. This point of view is maintained by Carnap, since The Logical Structure of the World (1928) and even more precisely since his subsequent contributions both on the principle of verification and on the refusal of metaphysics. ${ }^{8}$ The core thesis of Carnap's not cognitive ethics is presented in a short article of 1934, where the domain of practical decision and moral values is sharply distinguished from scientific knowledge as well as from verifiable statements. "The scientific consideration," Carnap argues, "does not determine the goal, but only the way leading to the goal that has been established [by our will]." (Carnap 1934: 259). Hence, in Carnap's view, an unbridgeable division subsists between the factual dimension and the normative sphere.

In 1936 Lewis, by contrast, makes it immediately clear that the problem consists just of establishing if it is actually possible to confine normative statements in the field of the meaningless or the "emotive" language (Lewis 1970: 152). In sketching an alternative solution, Lewis proposes to take into account a different conception of language from the formal-syntactical structure Carnap had privileged. Though Lewis was not influenced by the "linguistic turn" opened by Wittegenstein's Tractatus, he seems here very sensitive to the different uses of language (both in everyday life and in the scientific context). The use he considered excessively neglected by the Vienna Circle is "expressive use," entailing the capability of expressing living experience, feelings, esthetic or moral appreciations, intuitions, imagination. Since that domain of human life seems, at first sight, to be quite different from the field of judgment, cognition, knowledge, and verification, a strange ambiguity - Lewis believes - arises when investigating the question of normativity and language use. Usually, and in Vienna in particular, expressive meanings have been neglected, assuming that the class of cognitive statements includes only verifiable, true or false propositions belonging to meaningful language. According to Lewis, this narrow categorization simply represents great "confusion," that we should address as the consequence of an unjustified criterion of verification "denying the possibility of objective meaning in the case of value-predications" (Lewis 1970: 157). A similar failure depends, moreover, on another failure concerning the conception of objectivity. objectivity (in the authentic pragmatist sense) presupposes and involves at once intersubjectivity, namely the possibility of communicating meanings beyond the risk not avoided by Carnap - of legitimating a sort of solipsism. To sum up, for Lewis the

European Journal of Pragmatism and American Philosophy, XI-1 | 2019 
"reasonable argument" unfortunately not shared by Carnap leads to the conclusion that "there is no law against defining intersubjective value-meanings to a community of behavior" (Lewis 1970: 158). As a consequence, it sounds just very "reasonable" to hold that "it would be highly paradoxical to say that such expressive statements are not true or false" (Lewis 1970: 155).

The challenge Lewis posed to the Vienna Circle was surely of the greatest significance. There is a further important difference that has typically been overlooked. For his part, schlick was indeed engaged in creating a scientific ethics free of metaphysics, questioning nevertheless the not cognitive status of ethics claimed by other followers of Logical Empiricism, as in the very influential case, for instance, of Ayer's emotive theory of values (Ayer 1946: 102-20). Schlick's naturalistic ethics was elaborated in his Problems of Ethics, published in 1930 and also quoted by Lewis in the article we examined above. At first glance, Schlick's work seems to be perfectly imbued with the linguistic turn inaugurated by Wittgenstein, as is easy to see by reading the programmatic declaration of the preface, where Schlick emphasizes that philosophy should not to be intended as a science or "a system of propositions," but rather as an activity. Not unlike the conception of philosophy that Schlick had already outlined in his seminal article concerning the turning point in philosophy (Schlick 2008: 213-22), the task of philosophy ought to be defined as making clear the sense of scientific propositions or discovering their meaning. Properly speaking, this is in no way a scientific enterprise, but only an activity which "constitutes the essence of philosophy; there are no philosophical propositions, but only philosophical acts" (Schlick 1939: xiii). Nonetheless, in his ethical inquiries Schlick aims to deliver a contribution to the "psychological knowledge" of human moral behavior, the foundation of ethics being a psychological one: ethics is, any commitment to Wittgenstein's insights about ethics and values notwithstanding, a "factual science" (Schlick 1939: 20-2). ${ }^{9}$

18 That being said, it is worth noticing that ethics as psychological science or - put otherwise - as a cognitive and naturalistic discipline implies the overcoming of the "great division," namely the division between factual sciences and normative sciences. ${ }^{10}$ For Schlick this kind of opposition is "fundamentally false" (Schlick 1939: 17) and he insists that philosophers ought to conceive of ethics as a science of human reality. As a consequence it appears perfectly right to dismiss Kantian ethics and, more generally, the "pride of those philosophers who hold the questions of ethics to be the most noble and elevated of questions just because they do not refer to the common is but concern the pure ought (das reine Sein-sollende)" (Schlick 1939: 21). In evident opposition to Carnap, Schlick suggests that ethics requests an explanation (Erklärung) both of moral judgment and of moral conduct: because the "essence of moral" is explicable only through the exploration of the causes of human actions, i.e. of their order and regularity, the proper method of ethics is a psychological one. In this sense ethics is characterized not by its supposed independence from experience, but rather by its seeking of truth (Schlick 1939: 26-30).

19 Ultimately, Schlick's approach to ethical problems involves the opposition to the traditional views of both values and ethics of values that represented a widespread trend within the German philosophy at that time (in this connection one could mention, for instance, figures such as Heinrich Rickert or Max Scheler). According to Schlick, contrary to the wrong conception of values as "absolute" and totally independent from both psychological experience and psychological process of evaluation, the principle of 
verification can be applied to the field of values too. Values are not valid "in themselves" (an sich), but are the result of a psychological genesis, so that they are rooted in empirical state of affairs and, what is more important, they can be verified in light of some given psychological facts. Because of the psychological foundation of values and evaluating acts, it seems fully justified to find "the verification of a proposition concerning value ( Wertaussage) in the occurrence of a definite experience." The criterion of verification regarding moral values lies therefore in finding - as Schlick says - the "corresponding experience," that is "the feeling of pleasure" they awake. This feeling completely exhausts "the essence of value" (Schlick 1939: 105).

Let us turn now to Lewis. The critical attitude he takes toward Carnap cannot be considered as valid in the case of Schlick either. To begin with, Lewis is in accordance with Schlick regarding the empirical status of any sort of evaluation, which can be verified and, accordingly, tested as truth or false. As Lewis will suggest, "evaluations are a form of empirical knowledge, not fundamentally different in what determines their truth or falsity, and what determines their validity or justification, from other kinds of empirical knowledge" (Lewis 1946: 365). In spite of his deep commitment to Kant's ethics, Lewis remains a veritable pragmatist in considering human actions in the light of the consequences we can foresee, so that, in doing so, we are dealing with "one of the most essential of cognitive capacities" (ibid.). This places him at quite some distance from Schlick. In framing this conceptual space for ethics and value judgments, Lewis attempts to seriously take into account the problem of the objectivity of the ethical sphere, inasmuch as this sphere belongs to inter-subjectivity, to human communication, and to a project of social life universally desirable as rich and rationally oriented by common goals. In this context Lewis stresses again and again how it is important to correctly define the role of the "final test of judgment," which consists - in few words - of prediction and verification (Lewis 1970: 173-4).

There is also something else in common between Lewis and Schlick, albeit surely not between Lewis and Carnap. Lewis and Schlick share the basic assumption that both ethical values and judgments (or propositions) exhibit a cognitive content, being therefore verifiable in the broader sense of verificationism as it was discussed during the 1930s in Vienna as well as at Harvard. By contrast, in comparing Lewis's and Schlick's concept of experience one can conclude that Schlick's was patently narrower than Lewis'. As Sandra Rosenthal has pointed out, for Lewis "means and ends are inextricably fused in the holistic nature of ongoing experience in its temporal flow," whereas "his ethics integrates the importance of consequences and the role of imperatives rooted in our natural capacities as temporal, goal-oriented, problem-solving beings" (Rosenthal 2007: $139,151)$. Whether or not starting from such a conception of experience would have made it possible to enlarge and enrich the insights of the Vienna Circle in the period of the "cross-fertilization" between Logical Empiricism and Pragmatism is a question demanding not only historical, but also, and especially, systematic considerations. But this is, of course, a task for further research. 


\section{BIBLIOGRAPHY}

AYER Alfred J., (1946), Language, Truth and Logic, 2nd edition, New York, Dover.

AYER Alfred J., (1977), Part of my Life, London, Collins and Sons.

BECK Lewis W., (1953/54), “Die Kantkritik von C. I. Lewis und der analytischen Schule," Kant-

Studien, 45, 3-20.

BECK Lewis W., (1968), “The Kantianism of Lewis," in Paul A. Schilpp (ed.), The Philosophy of

C. I. Lewis, La Salle (Illinois)-London, Open Court-Cambridge University Press, 271-85.

BONNET Christian, (2001), “Le positivisme éthique de Schlick,” Les Études philosophiques, juillet-

septembre, 371-85.

CALCATERRA Rosa M., (2009), “L'a priori pragmatico di Clarence Irving Lewis," Discipline Filosofiche, $29(2), 103-20$.

CAlCATERra Rosa M., (2015), “Il pragmatismo concettuale di Clarence Irving Lewis," in Giovanni Maddalena \& Giancarlo Marchetti (eds), Il pragmatismo. Dalle origini agli sviluppi contemporanei, Roma, Carocci, 157-68.

CARNAP Rudolf, (1934), “Theoretische Fragen u. praktische Entscheidungen,” Natur und Geist, II, 257-60.

CARNAP Rudolf, (2003), The Logical Structure of the World and Pseudoproblems in Philosophy, trans. Rolf A. George, Chicago and La Salle, Open Court.

CHAUVIRÉ Christiane, (2001), "De Cambridge à Vienne. La maxime pragmatiste et sa lecture vérificationniste," in Jan Sebestik \& Antonia Soulez (eds), Le Cercle de Vienne. Doctrines et controverses, Paris, L'Harmattan, 43-58.

FERRARI Massimo, (2017), "William James and the Vienna Circle," in Sami Pihlström, Friedrich Stadler \& Niels Weidtmann (eds), Logical Empiricism and Pragmatism, Wien/New York, Springer, $15-42$.

FERRARI Massimo, (2018), "Felicità e conoscenza in Schlick," in Paola Rumore (ed.), Momenti di felicità. Per Massimo Mori, Bologna, Il Mulino, 93-114.

FONNESU Luca, (2006), Storia dll'etica contemporanea, Roma, Carocci.

FRIEDL Johannes, (2013), Konsequenter Empirismus. Die Entwicklung von Moritz Schlicks Erkenntnistheorie im Wiener Kreis, Wien-New York, Springer.

ноокwаY Christopher, (2013), “The Principle of Peirce and the Origins of Pragmatism," in Alan Malachowksi (ed.), The Cambridge Companion to Pragmatism, Cambridge, Cambridge University Press, 17-35.

KEGLEY Jacqueline A. K, (2017), “C. I. Lewis? A Significant Figure in American Pragmatism: Tracing Lines of Influences and Affinities of Themes and Ideas," in Peter Olen \& Carl Sachs (eds), Pragmatism in Transition. Contemporary Perspectives on C. I. Lewis, Cham, Palgrave Macmillan, 11-39. LEWIS Clarence Irving, (1918), A Survey of Symbolic Logic, Berkeley, University of California Press. 
LEWIS Clarence Irving, (1929), Mind and World Order. Outline of a Theory of Knowledge, London, Scribner's Sons.

LEWIS Clarence Irving, (1946), An Analysis of Knowledge and Valuation, La Salle (Illinois), The Open Court Publishing.

LEWIS Clarence Irving, (1970), Collected Papers of Clarence Irving Lewis, edited by John D. Goheen \& John L. Mothershead Jr., Stanford (California), Stanford University Press.

LIMBECK-LILIENAU Christian, (2012), “Carnap's Encounter with Pragmatism,” in Richard Creath (ed.), Rudolf Carnap and the Legacy of Logical Empiricism, Dordrecht/Heidelberg/London/New York, Springer, 89-111.

MORMANN Thomas, (2006), "Werte bei Carnap," Zeitschfrift für Philosophie und philosophische Forschung, 60, 169-89.

MORMANN Thomas, (2012), “Toward a Theory of the Pragmatic A Priori: From Carnap to Lewis and Beyond," in Richard Creath (ed.), Rudolf Carnap and the Legacy of Logical Empiricism, Dordrecht/ Heidelberg/London/New York, Springer, 113-32.

MORRIS Charles, (1937), Logical Positivism, Pragmatism and Scientific Empiricism, Paris, Hermann. MURPHEY Murray G., (2005), C. I. Lewis. The Last Great Pragmatist, Albany, State University of New York Press.

MURPhey Murray G., (2006), “C. I. Lewis,” in John R. Shook \& Joseph Margolis (eds), A Companion to Pragmatism, Oxford, Blackwell, 94-100.

NEURATH Otto, (1983), Philosophical Papers 1913-1946, ed. by Robert S. Cohen \& Marie Neurath, Dordrecht/Boston/Lancaster, Reidel.

OLEN Peter, (2017), "Diverging Paths? Conceptual Pragmatism and Logical Empiricism," in Peter Olen \& Carl Sachs (eds), Pragmatism in Transition. Contemporary Perspectives on C. I. Lewis, Cham, Palgrave Macmillan, 63-77.

QUINE Willard V. O., (1981), “The Pragmatists' Place in Empiricism,” in Robert J. Mulvaney \& Philipp M. Zeltner (eds), Pragmatism: Its Sources and Prospects, Columbia, University of South Carolina Press, 21-39.

RICHARDSON Alan W., (2003), "Logical Empiricism, American Pragmatism, and the Fate of Scientific Philosophy in North America," in Gary L. Hardcastle \& Alan W. Richardson (eds), Logical Empiricism in North America, Minneapolis-London, University of Minnesota Press, 1-24.

Rosenthal Sandra B., (2007), C. I. Lewis in Focus. The Pulse of Pragmatism, Bloomington and Indianapolis, Indiana University Press.

SCHLICK Moritz, (1939), Problems of Ethics, trans. by David Rynin, New York, Prentice-Hall. SCHLICK Moritz, (1974), General Theory of Knowledge, trans. by Albert E. Blumberg, with an introduction by Albert E. Blumberg \& Herbert Feigl, Wien, Springer.

SCHLICK Moritz, (1979), Philosophical Papers, vol. I: (1909-1922), edited by Henk L. Mulder \& Barbara F. B van de Velde-Schlick, trans. P. Haeth, Dordrecht/Boston/London, Reidel.

schlick Moritz, (2008), Kritische Gesamtausgabe, Abteilung I, vol. 6, Die Wiener Zeit. Aufsätze, Beiträge, Rezensionen 1926-1936, edited by Johannes Friedl \& Heiner Rutte, Wien-New York, Springer.

SIEGETSLEITNER Anne, (2014), Ethik und Moral im Wiener Kreis. Zur Geschichte eines engagierten Humanismus, Köln-Weimar, Böhlau. 
STADLER Friedrich, (2003), “The 'Wiener Kreis' in Great Britain: Emigration and Interaction in the Philosophy of Science," in Edward Timms \& John Hughes (eds), Intellectual Migration and Cultural Transformation. Refugees from National Socialism in the English-Speaking World, Wien-New York, Springer, 155-79.

STADLER Friedrich, (2007), "History of the Philosophy of Science. From Wissenschaftslogik (Logic of Science) to Philosophy of Sciences: Europe and America, 1930-1960," in Theo Kuipers (ed.), Handbook of the Philosophy of Science: General Philosophy of Science - Focal Issues, Amsterdam, Elsevier, 577-658.

STERN-GILLET Suzanne, (1983), “Schlick's 'Factual Ethics'," Revue Internationale de Philosophie, $144-145,145-62$.

STUMP David J., (2011), “Arthur Pap's Functional Theory of the A Priori,” Hopos, I, 273-89.

STUMP David J., (2015), Conceptual Change and Philosophy of Science. Alternative Interpretations of the A Priori, New York, Routledge.

STUMP David J., (2017), “The Pragamtic Theory of A Priori,” in Peter Olen \& Carl Sachs (eds), Pragmatism in Transition. Contemporary Perspectives on C. I. Lewis, Cham, Palgrave Macmillan, 147-67. ZAREBSKI Tomasz, (2017), "Sellars and Lewis on the Given and Empirical Knowledge," in Peter Olen \& Carl Sachs (eds), Pragmatism in Transition. Contemporary Perspectives on C. I. Lewis, Cham, Palgrave Macmillan, 199-217.

\section{NOTES}

1. These articles are now collected in Volume 6 of Schlick's works (Schlick 2008).

2. Zarebski 2017 has very well shown that Lewis's epistemology is immune to Sellar's criticism of the "myth of the given."

3. On this issue see in particular Kegley (2017: 20).

4. As Rosenthal (2007: 41) points out: "Lewis emphatically rejects as epistemologically untenable the nominalist conception that individuals are the first knowables and that individuals are primitively determinable by ostensive reference. It is only by reference to intentional meaning as criterion in mind by which one applies or refuses to apply a term that denotation is possible, for we must first have criteria for determining what experiences are relevant."

5. This example had been already formulated by Schlick in his article on positivism and realism (1932), which Lewis likewise had in mind (Schlick 2008: 332).

6. See furthermore (Schlick 2008: 743): "Solipsism is nonsense, because its starting-point, the egocentric predicament, is meaningless."

7. Olen 2017 suggests that Schlick's and Lewis's point of views are patently quite different and they do not allow for a convincing claim on the convergence between Logical Empiricism and Pragmatism. Olen still seems to consider Schlick and Carnap as the common targets of Lewis's criticism, thereby overlooking the fact that Carnap's formal language surely represents a very particular declination of verificationism. Lewis's skeptical attitude toward Carnap does not overlap with his doubts toward Schlick. See especially what Lewis remarks on in the late article Logical Positivism and Pragmatism by referring to Carnap's Philosophy and Logical Syntax: "The logical-positivistic theory [i.e. Carnap] fails to distinguish between syntactic or linguistic meaning - a relation of one verbal expression to other verbal expressions - and empirical meaning, which concerns the relation of expressions to what may be given in experience." (Lewis 1970: 96). This last statement ("the relation of expressions to what may be given in 
experience") is just the point of Schlick's unfortunately only sketched conception of Konstatierungen (Friedl 2013: 179-244).

8. To tell the truth, in 1928 Carnap was not so clear in questioning the not cognitive status of values (see Carnap 2003: 233-4; and Mormann 2006). In any case, Lewis was very well acquainted with Carnap's major work, which he had carefully studied (Murphey 2005: 221).

9. It is worth noticing that in his article of 1932 The Future of Philosophy Schlick underlines the scientific characters of ethics (and esthetics) in these terms: "Ethics and esthetics certainly do not yet possess sufficiently clear concepts; most of their work is still devoted to clarifying them, and therefore it may justly be called philosophical. But in the future they will, of course, become a part of the great system of the sciences." (Schlick 2008: 388).

10. On Schlick's ethics see Stern-Gillet 1983, Bonnet 2001, Fonnesu (2006: 240-3), Siegetsleitner (2014: 265-331) and Ferrari 2018.

\section{ABSTRACTS}

This paper explores the philosophical relationship between Clarence Irving Lewis and Moritz Schlick, questioning their understanding of verificationism. At stake is not only the crucial point of the possibility of verifying statements regarding, for instance, the other side of the moon, but also the proper status of ethical values in opposition to, or in connection with, scientific propositions grounded in experience. This latter aspect can better explain how both Lewis and Schlick understand the notion of experience in general, posing the conceptual framework within which Pragmatism and Logical Empiricism established a dialogue in the 1930s but still worthy of closer inquiry.

\section{AUTHOR}

\section{MASSIMO FERRARI}

Università degli Studi di Torino massimo.ferrari[at]unito.it 